\title{
Diagnosi azkarrera bideratutako gailu mikro-fluidikoen garapen eta azterketa
}

\author{
(Development and characterization of microfluidic devices \\ for rapid analysis systems)
}

Jaione Etxebarria-Elezgarai ${ }^{1 *}$, Susana Carregal-Romero ${ }^{2}$, Charles Lawrie $e^{3,5}$, Fernando Benito-Lopez ${ }^{4}$, Lourdes Basabe-Desmonts ${ }^{1,5}$

${ }^{1}$ BIOMICS-microfluidics Research group, Microfluidics Cluster UPV/EHU ikerketa taldea, Zoologia eta Animalia Zelulen Biologia Saila, Euskal Herriko Unibertsitatea, Gasteiz

${ }^{2}$ Bionanoplasmonics Laboratory, CIC biomaGUNE, Donostia

${ }^{3}$ Onkologia Saila, Biodonostia Osasun Ikerketa Institutua, Donostia

${ }^{4}$ AMMa LOAC Research Group, Microfluidics Cluster UPV/EHU ikerketa taldea, Kimika Analitikoa Saila, Euskal Herriko Unibertsitatea, Gasteiz

${ }^{5}$ IKERBASQUE Zientziarako Euskal Fundazioa, Bilbo

*jaione.etxebarria@ehu.eus

DOI: $10.1387 /$ ekaia.17997

Jasoa: 2017-07-14

Onartua: 2017-10-27

Laburpena: Lan honetan minbiziaren diagnosi goiztiarrerako eta tratamenduen egokitzapenerako kontzeptu berri bat aurkezten da, non gailu hibrido miniaturizatu batekin odoleko DNA zirkulatzailea analizatuz, kasuan kasuko mutazioaren presentziarik ote dagoen ezagutu nahi den. Egitura hibridodun gailua paperezko zein material polimerikozko mikro-egituraz osatuta egongo da, eta laginaren prestakuntzarako, seinalearen anplifikaziorako eta detekziorako modulu ezberdinak izango ditu. Halaber, analisiak in situ egin eta emaitzak denbora gutxian eskuratzeko aukera emango digu, kostu gutxiko analisiekin pazientearen jarraipen egokituago bat egin ahal izateko.

Hitz gakoak: mikro-teknologiak, diagnostiko azkarra, in situ analisia, txip mikro-fluidiko hibridoak.

Abstract: This work presents a new concept of a hybrid Point-of-Care (POC) device developed for the detection of cancer biomarkers in blood, circulating DNA, for early cancer diagnostics. The device is composed of both, paper and polymeric based selfpowered microfluidic structures and it includes several modules with different func- 
Jaione Etxebarria-Elezgarai, Susana Carregal-Romero, Charles Lawrie, Fernando Benito-Lopez, Lourdes Basabe-Desmonts

tions: sample preparation, signal amplification and detection. This POC device will enable in situ analysis and quick delivery of results, as well as a low cost tool for diagnostics which could impact clinical decision making and personalized medicine.

Keywords: microtechnology, rapid diagnostic systems, in situ analysis, hybrid microfluidic devices.

\section{SARRERA}

Azken urteetan mikro-teknologietan izandako aurrerapenek Lab-ona-chip (LOC) edo Point-of-Care (POC) diagnosi azkarreko gailu miniaturizatuak garatzea ahalbidetu dute. Teknologia berritzaile horiek hainbat ezagutza esparru biltzen dituzten sistema integratu multifuntzionalak dira, eta aplikazio mediko eta biologikoetarako aukera handiak eskaintzen dituzte $[1,2]$. Abantaila nagusiak erantzun-denbora laburrak, erreaktibo eta laginen erabilera minimoak, eta analisi biologikoen errendimendu hobeak dira [3]. Gainera, miniaturizazioari esker, laborategitik urrun gaixotasunak in situ detektatzeko balio dute, azkar batean emaitzak jakinaraziz [4]. Gaur egun, erronka nagusia sentikortasun eta efikazia altuko gailu autonomo eta automatizatuak sortzea da, betiere erabilera erraza eta kostu baxua eskainiz. Bestetik, sistema gehienek lagina bere egoera normalean erabiltzea bilatzen dute, lagina zuzenean eta inolako aurretratamendurik gabe analizatu ahal izateko [5].

Lan honetan, INDICATE kontzeptu berritzailea aurkezten da, «In vitro minbizi diagnosirako testa» deritzona (IN vitro DIagnostics for CAncer TEsting) eta ClearBlue ${ }^{\mathrm{TM}}$ obulazio testean eta antzeko in vitro diagnosi tresnetan inspiratuta dagoena. INDICATE gailua pazientearen odol lagin bat erabiliz minbiziaren diagnostiko goiztiarra ahalbidetuko duen «biopsia-likidoa» da. 1. irudian erakusten den prototipoaren izaera ez-inbaditzaile eta eramangarriak oso erakargarri egiten du gailu hau, medikuaren kontsultan bertan, laborategitik urrun eta makina espezializatu garestirik erabili gabe, minbizidun pazienteen gaixotasunaren zein tratamenduen jarraipena egiteko.

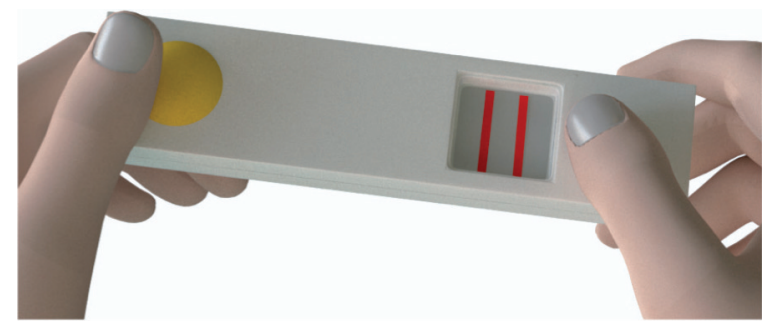

1. irudia. Haurdunaldi testaren gisako INDICATE tresna eramangarriaren diseinu orokorra. 


\section{ARLOKO EGOERA ETA IKERKETAREN HELBURUAK}

POC sistema analitikoak aplikazio errealetan inplementatu eta emaitza onak lortu ahal izateko beharrezkoa da kontrol mikro-fluidiko zorrotza izatea zirkuitu fluidiko guztian zehar. Gaur egun kontrol mikro-fluidikorako osagai ugari aurki ditzakegu, eta horien artean mikro-balbulak eta mikro-ponpak dira garrantzitsuenak. Analisirako sistema autonomoak egiteko orduan osagai autopropultsatuak erabiltzea interesgarria denez, azken urteetan mota horretako osagaien sorta zabala aurki daiteke [6-8]. Orain arte fabrikazio teknika eta material ezberdinak erabili izan dira halako osagaiak garatzeko. Tradizionalki materialik ohikoenak beira eta silizioa izan dira, baina gaur egun jada material berri ugari erabiltzen dira, horien artean zabalduenak polimeroak izanik. Horrekin batera, fabrikazio teknika berriak sortu dira azken hamarkadetan: moldekatze termikoa, injekzio bidezko moldekatzea, laser bidezko fabrikazioa edo azkenaldian indarra hartzen ari den 3D inprimaketa, esaterako [9]. Joera horri jarraikiz, suspertzen ari den teknologia bat material polimerikoen desgasifikazio bidezko zirkuitu fluidikoen kontrola da. Mikro-ponpak material elastomeroetan modularki diseinatzeko aukera dago, gero txip mikro-fluidikoei gehituz mikro-kanalen barruko emarien kontrola sustatzeko. Kasu honetan, emaria ponparen diseinuaren menpekoa da soilik, eta ez txiparen menpekoa [10].

Ildo horretan, lan honen helburua INDICATE teknologia garatzeko egindako aurrerapenak erakustea da, osagai mikro-fluidikoen diseinua, fabrikazioa eta funtzionamendua erakutsiz. INDICATE polimerozko egitura mikro-fluidikoz eta alboko fluxudun paperezko tira batez osatuta egongo da (inglesez Lateral Flow Assay, LFA). 3D inprimaketa bidezko fabrikazioa erabiliko da zirkuitu mikrofluidikoak ekoitzi eta likidoaren ibilbiderako mikro-kanalak eta erreaktiboentzako gordailuak polimero akriliko zurrunetan lortzeko. Polimerozko txip horretan kontrolatutako emaria sortzeko PoliDiMetilSiloxano (PDMS) elastomerozko ponpa autopropultsatuak erabiliko dira. Azkenik, INDICATE gailuak paperezko LFA egitura bat izango du begi hutsez analitoa detektatu ahal izateko. LFAetan likidoaren mozioa paperak berez daukan kapilaritate ahalmenari esker lor daiteke, baina likido kantitate handien erabilera bermatzeko material bereziak gehitu behar izaten zaizkie. Beraz, azkenik txip hibridoa garatuko da polimerozko, elastomerozko eta paperezko egiturak elkartuz, eta integrazioaren egokitasuna lagin bolumen handietarako (>200 ul) aztertuko da.

\section{INDICATE GAILURAKO OSAGAI MIKRO-FLUIDIKOEN DISEINU ETA GARAPENA}

INDICATE gailua sistema integratu multifuntzionala eta konplexua izango da, eta, ezagutza esparru ugariren fusioan oinarrituz, modulu bat 
Jaione Etxebarria-Elezgarai, Susana Carregal-Romero, Charles Lawrie, Fernando Benito-Lopez, Lourdes Basabe-Desmonts

baino gehiago bilduko ditu, analisia gauzatzeko beharrezko etapa biologiko eta mikro-fluidiko guztiak integratuz. Etapa horiek 2.1 irudiko eskeman erakusten dira, honako hau izanik jarraitu beharreko mekanismoa. Pazientearen odol lagina gailuan sartzean (2.1. irudiko (1) modulua), lehenik eta behin odol lagina garbitzen da gordailu itxurako filtroan, odoleko zelulak sedimentazio bidez kanporatuz eta odol plasma eskuratuz (2.2 irudia eta 2.1 irudiko (2) modulua). Analisian bilatzen den mutazioa plasma laginean egonez gero, eta bakarrik mutazio hori laginean dagoenean, DNA mutatua purifikatzen da (2.3, 2.4 irudiak eta 2.1 irudiko (3) eta (4) moduluak), eta urrezko nanopartikulekin (AuNP) elkartzen da aglomeratuak sortzeko (2.5 irudia eta 2.1. irudiko (5) modulua), horretarako espezifikoki diseinatuak izan diren zundak erabiliz (2.4, 2.5 irudiak eta 2.1. irudiko (4) eta (5) moduluak). Sortutako aglomeratu horiek uhin luzera zehatzeko laserrarekin irradiatzean berotu egiten dira (metalen efektu plasmonikoari esker) eta bero hori aurrez txipean gordeta dauden mikro-kapsula termosentikor batzuk apurtzeko erabiltzen da (2.6 irudia eta 2.1 irudiko (6) modulua). Ondorioz, mikro-kapsula horietan bilduta dauden milaka molekula koloratu

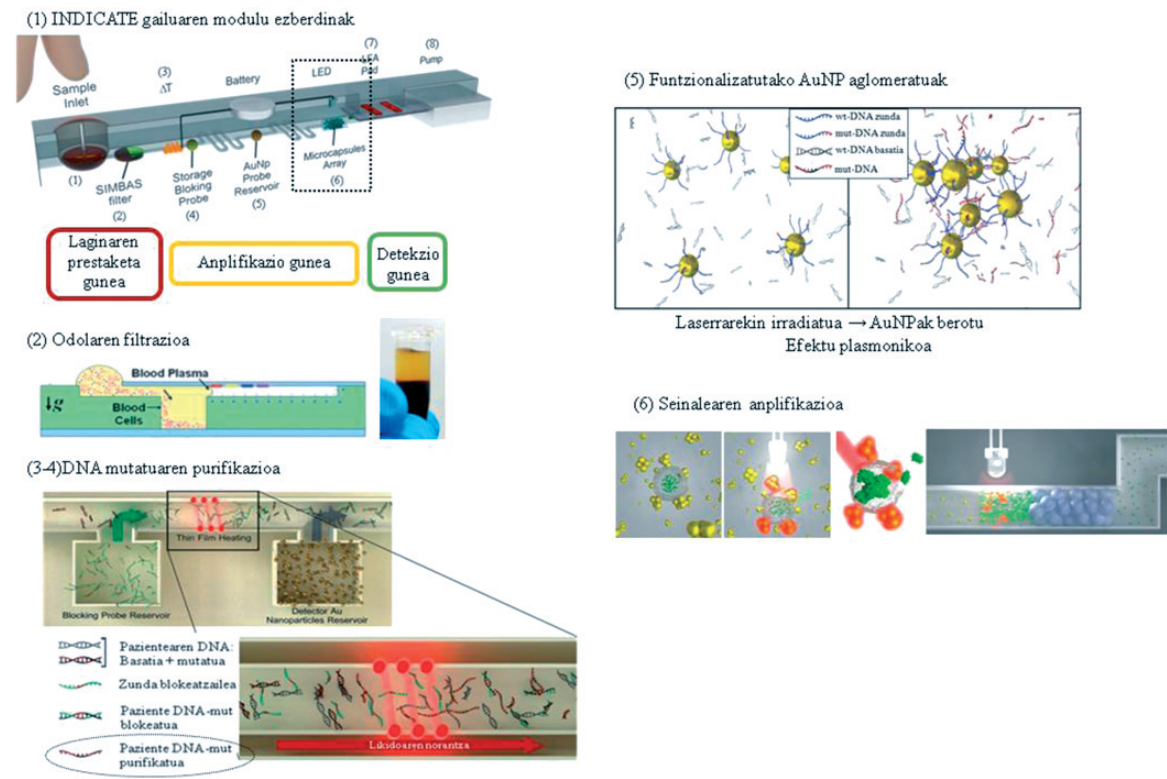

2. irudia. INDICATE gailuaren osagai nagusiak: Laginaren sarrerako gordailua (1.1), filtrazio gunea (2) eta (1.2), DNA desnaturalizatzeko berogailua (3) eta (1.3), pazientearen DNA mutatua purifikatzeko zunda blokeatzailearen gordailua (4) eta (1.4), pazientearen DNA mutatua harrapatzeko funtzionalizaturiko AuNP-en gordailua (5) eta (1.5), LED laserra eta mikro-kapsulen filtroa duen anplifikazio gunea (6) eta (1.6), alboko fluxudun paperezko detekzio gunea (1.7), eta emarien mugimendua sortzeko mikro-ponpa autopropultsatua (1.8). 
askatzen dira, eta horiek paperezko LFA tiran begi hutsez eta modu kualitatibo batean detektatzen dira (2.1. irudiko (7) modulua).

Kasuan kasuko mutazioarentzako DNA-zunda espezifikoak diseinatuko dira, bai pazientearen DNA mutatua purifikatzeko, bai eta AuNP-ak funtzionalizatzeko eta aglomeratu espezifikoak sortzeko. DNA mutatua pazientearen laginean aurkitzen denean bakarrik gertatuko da horren eta AuNP-en arteko lotura, eta ondorioz aglomerazioa. Are gehiago, kapsula termosentikorrak AuNP-en aglomerazioa gertatzean bakarrik apurtuko dira, erabilitako uhin luzera tartean banakako AuNP-ek sortu dezaketen beroa ez baita mikro-kapsulak apurtzeko nahikoa (AuNP-ak aglomeratzean haien absortzio banda banakako AuNP-en bandarekiko desplazatzen da) [11-13]. Beraz, anplifikazio mekanismoa aztertu nahi den mutazioarekiko espezifikoa da, eta, ohiko termoziklagailuak ez bezala, milaka seinale-molekularen askapen selektiboan oinarritzen da.

\subsection{D inprimaketa bidezko txip mikro-fluidikoen fabrikazioa}

Fabrikatu diren txip eta egitura mikro-fluidiko guztiak Creo Parametrics $2.03 D$ eta PreForm softwareekin diseinatu dira, eta 3D inprimaketa FormLab $1+$ inprimagailuan $50 \mu \mathrm{m}$-ko erresoluzioa eta material akriliko gardena (Formlab Clear resin FLGP CL02) erabiliz egin da. FormLab makinak estereolitografia teknologia erabiltzen du, eta $405 \mathrm{~nm}$-ko uhin luzerako laserra dauka erretxinari erreakzionarazteko. Inprimatutako piezak isopropanolezko bainu batean garbitzen dira, gogortu ez den erretxina kentzeko eta egituren emaitza hobetzeko. Ondoren erretxina guztiz gogortzeko, pieza $365 \mathrm{~nm}$-ko uhin luzerako argi ultramoredun lanpara batean ontzen utzi da 30 minutuz, eta 3 . irudian ageri direnak bezalako egiturak lortu dira.
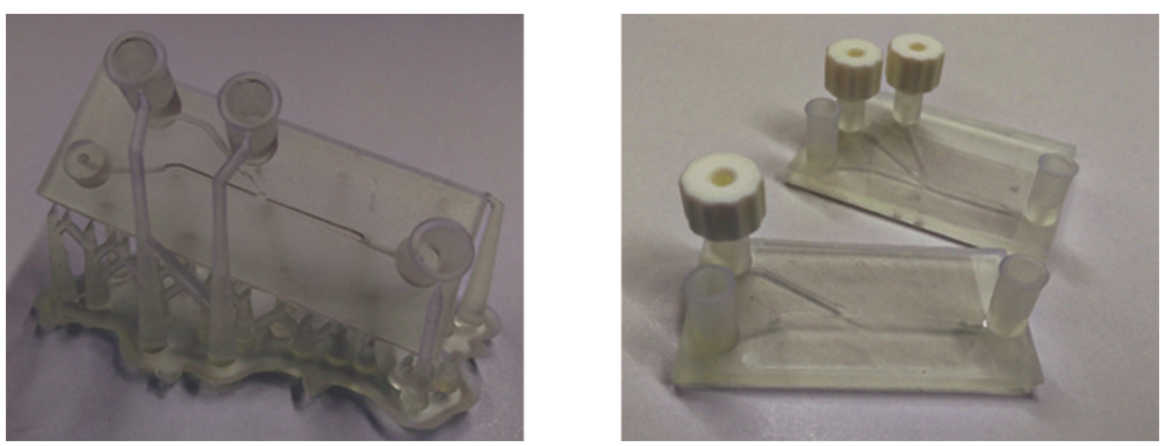

3. irudia. FormLab $1+3 \mathrm{D}$ inprimagailuan $50 \mu \mathrm{m}$-ko erresoluzioa eta material akriliko gardena erabiliz fabrikatutako txip mikro-fluidikoak. 
Jaione Etxebarria-Elezgarai, Susana Carregal-Romero, Charles Lawrie, Fernando Benito-Lopez, Lourdes Basabe-Desmonts

\subsection{PDMS mikro-ponpak}

Lehenago aipatu bezala, POC gailu bat garatu eta aplikazio errealetan emaitza egokiak lortzeko ezinbestekoa da likidoen mugimenduaren kontrola izatea, eta horretarako PDMSzko ponpak erabiltzea proposatu da lan honetan. 4. irudian ikus daitekeen bezala, elastomerozko ponpa autopropultsatuen funtzionamendua oso sinplea da. PDMSak bere barneko poroetan duen airea hutsune bidez ateratzen da, behin mikro-ponpa desgasifikatuta dagoenean (horrela paketatu eta biltegiratu daiteke) txiparen muturrean ezartzen da, eta barneko poroetako presio negatiboa orekatzeko asmotan mikro-kanaletako airea xurgatzen du. Ondorioz, airearen desplazamenduak mikro-kanaletako likidoa ere desplazarazten du, emaria sortuz.
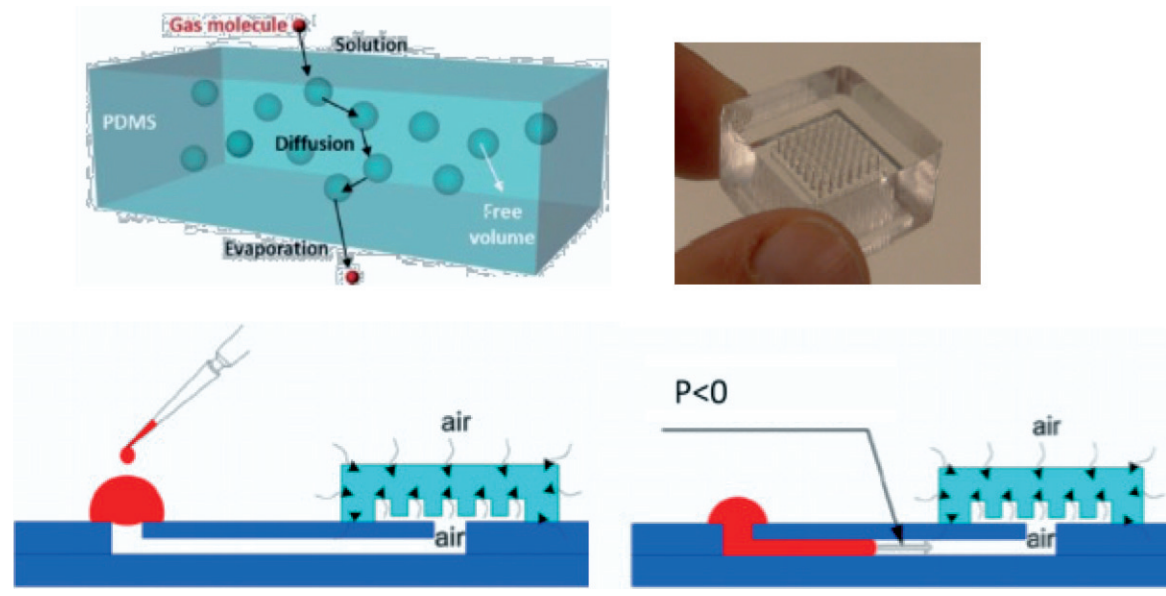

4. irudia. PDMS mikro-ponpa autopropultsatuen funtzionamendua.

Aurreko lan baten erakutsi genuenez, sortzen den emaria PDMSaren gainazaleko azaleraren araberakoa da [14]. Beraz, ponparen gainazal erabilgarria aldatuaz emari ezberdinak lor ditzakegu, eta gainazal hori handitzeko modu sinple bat ponpak elkarren gainean pilatzea da. 5. irudian ikus daitezkeen azken diseinuei esker emari gaitasun handia duten PDMS elastomerozko mikro-ponpak garatu ditugu, eta erabiltzen den kopuruaren arabera emari tarte ezberdinak lortzen dira. Horrela, batez beste $4 \mu \mathrm{l} / \mathrm{min}, 8 \mu \mathrm{l} / \mathrm{min}, 14 \mu \mathrm{l} / \mathrm{min}$ eta $20 \mu \mathrm{l} / \mathrm{min}$-ko emariak lortu dira ( $\mathrm{t}>4-5 \mathrm{~min}$ ) 1, 2, 3 eta 4 mikro-ponpa batera erabili direnean, hurrenez hurren. 


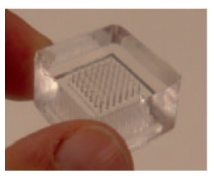

(1)

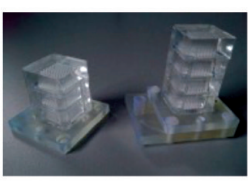

(2)

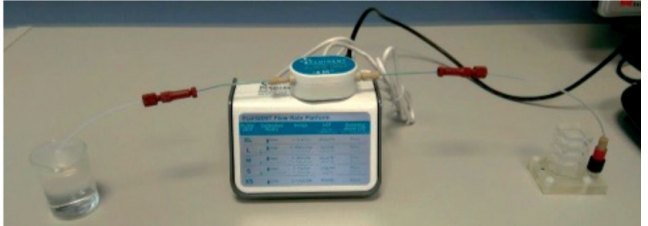

(3)

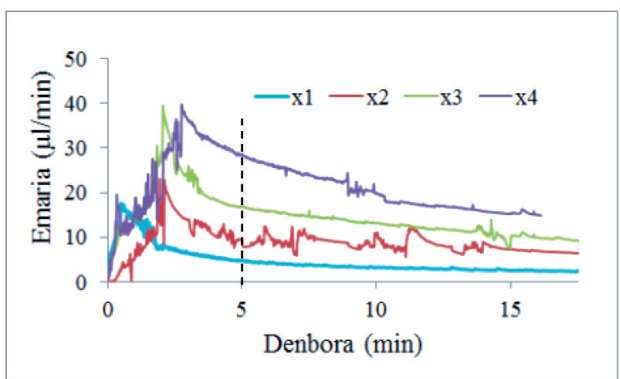

(4)

5. irudia. (1) PDMS mikro-ponpa unitarioa. (2) 3 eta 4 mikro-ponpa elkarrekin itsastean lorturiko emari altuko PDMS mikro-ponpak. (3) PDMS mikro-ponpen funtzionamenduaren analisirako erabili den emari-sentsorearen muntatzea. (4) 1, 2, 3 eta 4 mikro-ponpa erabilita lortzen diren emarien profila; mikro-ponpa horiek PSA (Pressure Sensitive Adhesive) zerrenda itsasgarri bat erabilita itsatsi dira elkarrekin eta 3D inprimaketa bidez fabrikatuko txip mikrofluidikoarekin.

\subsection{Odolaren filtrazioa}

Odol laginak boluntario osasuntsuetatik atera dira flebotomian adituak diren zerbitzu profesional baten bidez, eta odolaren koagulazioa ekiditeko EDTA estaldura duten BD Vacutainer ${ }^{\circledR}$ ontzietan biltegiratu dira. 6.1 irudian, 3D inprimaketa bidez fabrikatutako eta $100 \mu 1$-ko odol bolumenera egokitutako filtrazio modulua ikus daiteke. PDMS ponpa batez baliatuz, filtroan odola bere egoera normalean sartzen da, eta, 6.2. eta 6.3 irudietan erakutsi bezala, tanke zirkular guztia beteta dagoenean odoleko zelulak (globulu gorriak, zuriak eta plaketak) dekantazio bidez eliminatzen dira. Orduan tanketik plasma likidoa ateratzen da, 6.2 irudian marra zuri batekin bereizita ikusten dena. Horretarako, zelulen dekantazio abiadura tankean likidoak duen egoitza denbora baino altuagoa izan behar da. 
Jaione Etxebarria-Elezgarai, Susana Carregal-Romero, Charles Lawrie, Fernando Benito-Lopez, Lourdes Basabe-Desmonts

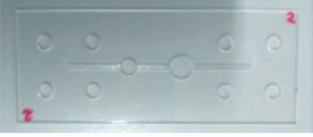

(1)
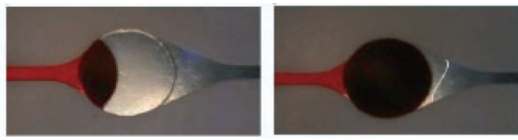

(2)

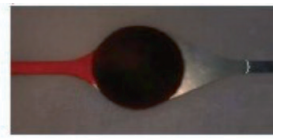

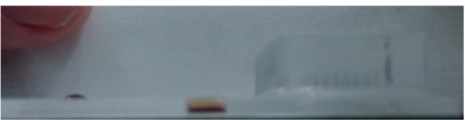

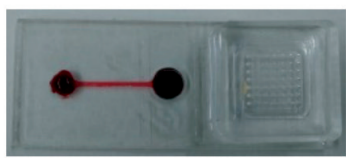

(3)

6. irudia. Odoleko zelulak filtratzeko 3D inprimaketa bidezko txip mikro-fluidikoa. Diseinua $100 \mu \mathrm{l}$ odol filtratzeko egokitu da, eta marra zuriak filtratutako plasma likidoaren frontea erakusten du.

\subsection{Anplifikazio modulua}

Anplifikazio moduluan molekula fluoreszenteak (dextrano-FITC) erabili dira seinale-molekula gisa, eta horiek $10 \mu \mathrm{m}-\mathrm{ko} \mathrm{SiO}_{2} / \mathrm{PDADMAC}$ (Poli(DiAlilDimetilAmonio Kloruro)) mikro-kapsula termosentikorren bar-

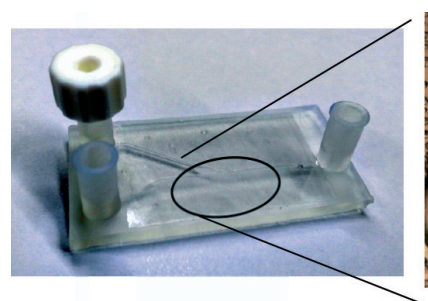

(1)

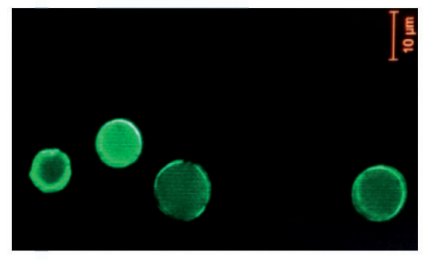

(4)

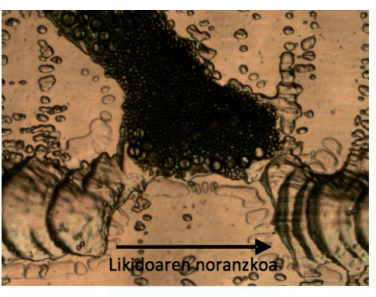

(2)

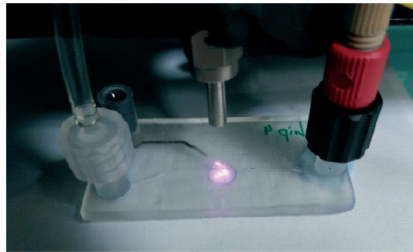

(5)

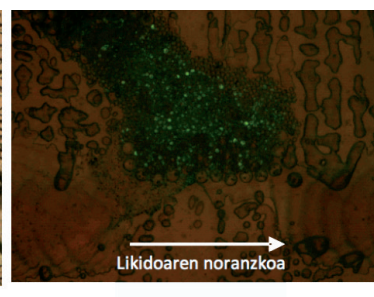

(3)

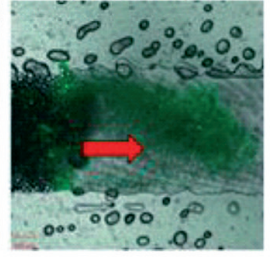

(6)

7. irudia. Anplifikazio modulua: (1) 3D inprimaketa bidezko txip mikro-fluidikoa, (2-3) mikro-kapsulak atxikita mantentzeko beirazko mikro-esferazko zutabea, laserraren zona definitzeko, (4) molekula fluoreszentez beteriko mikro-kapsula termosentikorrak, (5) laserrarekin erabilitako muntaia kapsulak zabaltzeko, (6) molekula fluoreszenteen askapena. 
nean sartu dira. Mikro-kapsulek laserra dagoen eremuan finkatuta egon behar dute, baldin eta AuNP aglomeratuak pasatzean beroa sortzea eta mikro-kapsulak beroaren bidez apurtzea nahi bada. Horretarako 3D inprimaketa bidez «anplifikazio zona» bat fabrikatu da beirazko mikro-esferazko ( $75 \mu \mathrm{m}$ Glass Beads, 59200-U Sigma Aldrich) filtro baten bidez mikro-kapsulak finkatzeko, 7.1, 7.2 eta 7.3 irudietan erakutsi bezala. Laser bidezko kapsulen apurketa eta molekula fluoreszenteen askapena aurrez prestatuko AuNP aglomeratuak erabiliz aztertu da. $800 \mathrm{~nm}$-ko uhin luzera eta 3.000 A-ko intentsitatea 3 minutuz erabiltzean dextrano-FITC molekulak askatzea lortu dela ikus daiteke 7.6 irudian.

\subsection{Txip hibridoa}

Azkenik plastikozko txipaz, paperezko tiraz eta elastomerozko ponpaz osatuko txip hibrido integratu bat fabrikatu da. Txip horretan, lagina LFAra iristean, paperak xurgatu egingo du kapilaritateari esker. Aplikazioan espero den laginaren kantitatea paperak xurga dezakeena baino askoz handiagoa izango denez, paperaren saturazioa ekidin eta lagin guztia detekzio gunetik pasatuko dela ziurtatu behar da. Horretarako paperean hidrogel disko bat integratu da, LFAtik pasatzen den likidoa eliminatzeko eta txiparen bukaerako gordailuan biltzeko.

8. irudian erakusten den esperimentuan guztira $300 \mu 1$-ko bolumena 3 zatitan sartu da txiparen sarreratik, bakoitzean $100 \mu 1$, kolore horiko likidoa lehenik, gorria bigarrenik eta urdina azkenik. Proba honetan frogatu da txip hibridoak $300 \mu$ l-ko bolumen batekin lan egin dezakeela integratutako hidrogel diskoari esker.

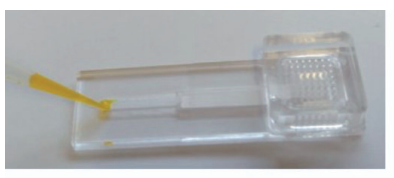

(1)

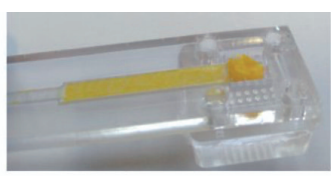

(2)

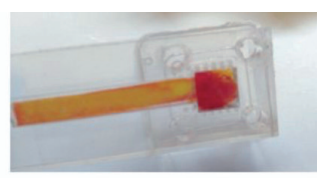

(3)

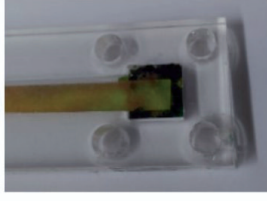

(4)

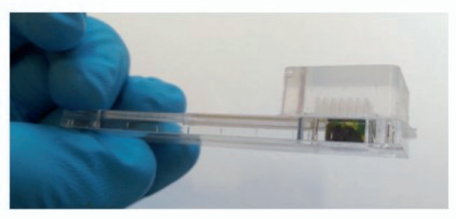

(5)

8. irudia. Plastikozko txipaz, paperezko tiraz, hidrogel disko batez eta elastomerozko ponpaz osatuko txip hibrido integratuan egindako froga fluidikoa. 
Jaione Etxebarria-Elezgarai, Susana Carregal-Romero, Charles Lawrie, Fernando Benito-Lopez, Lourdes Basabe-Desmonts

\section{ONDORIOAK}

INDICATE gailurako osagaiak 3D inprimaketa bidez fabrikatu dira. Osagai horien funtzionamendu egokiak erabilitako fabrikazio teknikaren baliozkotasuna baieztatzen du, etorkizunean modulu guztiak gailu bakarrean integratzea errazago eginez.

Odol filtroa $100 \mu 1$ odolekin erabili da, eta zelulak eliminatzeko eta plasma ateratzeko gai dela ziurtatu da. Kasu honetan, laginaren bolumen kantitatea 20 aldiz handitzea lortu da aurreko beste argitalpen batekin alderatuz [15]. Beraz, INDICATE gailurako ez da odol laginaren aurretiko prestaketarik beharko, baina gutxienez $200 \mu 1$-ra arteko filtrazio ahalmena lortzeko egokitu beharko da, proiektuko espezifikazioak bete daitezen.

Anplifikazio gunetik DNA kantitate txiki batekin sortutako AuNP aglomeratuak pasaraztean laserrarekin irradiatu eta molekula fluoreszenteak askatzea lortu da. Horrela, hasieran oso urria eta neurtezina den DNA kantitaterako aise neurtu daitekeen seinalea lortu da. Hurrengo esperimentuetan askapen hori kuantifikatu beharko da analisi parametro ezberdinetarako.

PDMS elastomerozko mikro-ponpak modulu unitario gisa garatu dira, eta unitate kantitatea handituz lortzen den likido emaria ere handitu egiten dela erakutsi da. Diseinurako askatasun horrek intereseko emari baldintzak bermatuko dituen mikro-ponpa fabrikatzea erraztuko du; izan ere, azken diseinuei esker lortutako emari tarteek POC gailu eramangarri eta autonomoak sortzeko baldintzak betetzen dituzte. Gainera, haien funtzionamendua oso sinplea denez eta erabili eta botatzekoak direnez, oso aproposak dira erabilera bakarreko test biologikoetarako.

Egitura hibridoa osatzeko plastikozko txipa, paperezko tira, hidrogel disko bat eta elastomerozko mikro-ponpa integratu dira. Gailu horiek guztiak konbinatuz eta mikro-ponpak sortzen duen hutsari eta paperaren kapilaritate ahalmenari esker likidoa mugitzea lor daitekeela erakutsi da. Gainera, erabilitako hidrogel diskoa txipetik pasatutako likido guztia gordetzeko gai dela ere ikusi da, bolumen altuko laginak erabiltzea ahalbidetuz detekzio gunean likidoarekin saturatu gabe.

\section{ETORKIZUNERAKO PLANTEATZEN DEN NORABIDEA}

INDICATE gaur egun ikerketa zentro eta enpresa ugariren parte-hartzearekin aurrera doan proiektua da, eta datozen urteetan teknologia hau garatuz joango dela espero da. Behin prototipoa definituta, garatutako teknologikoaren ezagutza industriara transferituko da, eta gailuaren serie altuak fabrikatuko dira eremu klinikoan haien baliozkotasuna jorratzeko. 


\section{ESKER ONAK}

Egileok gure esker ona adierazi nahiko genioke Eusko Jaurlaritzako Industria, Berrikuntza, Merkataritza eta Turismo Sailari, eta baita ere Eusko Jaurlaritzako Osasun Sailari, ELKARTEK 2015 deialdiko KK2015/0000088 zenbakidun eta RIS3 deialdiko 307616FKA4 zenbakidun diru laguntzekin, hurrenez hurren, ikerketa hau babesteagatik.

Gainera, egileok Euskal Herriko Unibertsitateko Marian Martínez de Pancorbo katedraduna eskertu nahiko genuke UPV/EHUko laborategi instalazioen erabilera gure eskura jartzeagatik, eta baita DNA Bankuko (SGIker) Maite Alvarez doktorea, laguntza tekniko eta pertsonalarekin eta Europako finantziazioarekin (FEDER eta FSE) laguntzeagatik. Azkenik, Adhesive Research zentroaren kolaborazioa ere aipatu nahiko genuke, PSA materialaren doako horniketarengatik.

Jaione Etxebarriak «2016ko UPV/EHUn ikertzaile doktoreak espezializatzeko kontratatzeko diru laguntzen deialdia» eskertu nahiko luke ESPPOC 16/65 zenbakidun laguntzarekin ikerketa hau babesteagatik. Era berean, Jaionek eskerrak eman nahiko lizkieke INDICATE proiektuko partzuergoan parte hartzen duten ikerketa taldeetako ikertzaileei.

Bestalde, Fernando Benito-Lopezek, Espainiako Ekonomia eta Lehiakortasun Ministerioko «Ramón y Cajal» Programako onuraduna denak, «European Union's Seventh Framework Programme (FP7) for Research, Technological Development and Demonstration, 604241» proiektua eskertu nahiko luke.

\section{BIBLIOGRAFIA}

[1] Dittrich P.S., Tachikawa K., Manz A. 2006. «Micro total analysis systems. Latest advancements and trends». Analytical Chemistry, 78, 3887-3908.

[2] Vilkner T, Janasek D, Manz A. 2004. «Micro total analysis systems. Recent developments». Analytical Chemistry, 76, 3373-3385.

[3] Thorsen T., Maerkl S.J., Quake S.R. 2002. «Microfluidic Large-Scale Integration». Science, 298, 580-584.

[4] Piraino F., Volpetti F., Watson C., Maerkl S.J. 2016. «A Digital-Analog Microfluidic Platform for Patient-Centric Multiplexed Biomarker Diagnostics of Ultralow Volume Samples». ACS Nano, 10, 1699-1710.

[5] Gubala V., Harris L.F., Ricco A.J. et al. 2012. «Point of care diagnostics: status and future». Analytical Chemistry, 84, 487-515.

[6] Cha K.J., Kim D.S. 2011. «A portable pressure pump for microfluidic labon-a-chip systems using a porous polydimethylsiloxane (PDMS) sponge». Biomedical Microdevices; 13, 877-883. 
Jaione Etxebarria-Elezgarai, Susana Carregal-Romero, Charles Lawrie, Fernando Benito-Lopez, Lourdes Basabe-Desmonts

[7] Kokalj T., Park Y., Vencelj M. et al. 2014. «Self-powered imbibing microfluidic pump by liquid encapsulation: SIMPLE». Lab on a Chip; 14.

[8] Liang D.Y., Tentori A.M., Dimov I.K., Lee L.P. 2011. «Systematic characterization of degas-driven flow for poly(dimethylsiloxane) microfluidic devices». Biomicrofluidics, 5.

[9] Amin R. et al. 2016. «3D-printed microfluidic devices». Biofabrication, 8.

[10] Li G., Luo Y., Chen Q. et al. 2012. «A «place n play» modular pump for portable microfluidic applications». Biomicrofluidics, 6, 14118-1411816.

[11] Haiss W., Thanh N.T.K., Aveyard J., Ferning D.G. 2007. «Determination of size and concentration of gold nanoparticles from UV-vis spectra». Analytical Chemistry, 79, 4215-4221.

[12] Khlebtsov N.G., Dykman L.A. 2010. «Optical properties and biomedical applications of plasmonic nanoparticles». J Quant Spectrosc Ra, 111, 1-35.

[13] Vivero-Escoto J.L., Slowing I.I., Wu C.W., Lin V.S. 2009. «Photoinduces intracellular controlled release drug delivery in human cells by gold-capped mesoporous silica nanosphere». J Am Chem Soc, 131, 3462-3463.

[14] Ruiz I., Veci I., Tijero M. et al. 2015. «Self-powered high flow capacity polymeric microfluidics». microTAS.

[15] Dimov I.K., Basabe-Desmonts L., García-Cordero J.L. et al. 2010 «Standalone self-powered integrated microfluidic blood analysis system (SIMBAS)». Lab on a Chip; 11:845-850. 